\title{
Current Issues on Vocational and Technical Education in Nigeria
}

\author{
Pattarawat Jeerapattanatorn \\ Post-Doctoral Fellow, University of Ilorin, Nigeria, and \\ Professor, Kasetsart University, Thailand
}

\section{Doi:10.5901/jesr.2013.v3n10p121}

\begin{abstract}
Vocational and Technical Education (VTE) is education which aims to deliver people with knowledge, skills and competences required in particular occupations or more broadly on the labour market. VTE is very important as it develops a person for life and it affords the competences which are necessary in a democratic and knowledge-based society. Hence, VTE should be a vital aspect of the educational process in all countries. Most civilised countries realise valued role of the VTE as an effective mechanism for career development of people. However, a number of developing countries have been facing some difficulties to conduct quality VTE in their countries, Nigeria is included. Current issues towards VTE in Nigeria have been discussed in scholarly published documents indicating a need for change. The objective of this paper was to synthesize selected documents indicating current issues on VTE in Nigeria for the next step of social and economic development.
\end{abstract}

Keywords: Vocational and Technical Education, Issues, Nigeria

\section{Introduction}

The Federal Republic of Nigeria (2004) defined Vocational and Technical Education (VTE) as a comprehensive term referring to those aspects of the educational process involving, in addition to general education, the study of technologies and related sciences and acquisition of practical skills, attitudes, understanding and knowledge relating to occupations in various sectors of economic and social life. VTE consists of vocational training packages or educational activities for improving people's current careers and vocational training packages or educational activities for the unemployed. VTE is important as it enriches a person for life and it provides the competences which are necessary in a democratic society. Societal and economic development depends on the strength of VTE as it provides access to skills and entry routes into the labour market. For underprivileged and marginalised groups in particular, it can be an important route towards a better life. VTE takes a significant role to solve unemployment problems in developing countries.

In Nigeria, unemployment rate increased to $23.9 \%$ in 2011 from $21.1 \%$ in 2010 with youth unemployment rate at $56 \%$ (National Bureau of Statistics, 2012). Unemployment is one of major problems in Nigeria since it has been increasing for years. This might reflect how the government dealt with Vocational and Technical Education in Nigeria.

Policies and practices implemented by the Federal Government of Nigeria could be very influencing factors for those mentioned VTE issues. Government organizations responsible for VTE policy and practice may have some revisions in order to improve vocational development of the country. This study tried to investigate VTE policies and practices as well as problems within Nigeria. The study also emerged some possible solutions for the existing problems. 


\section{Objectives}

To explore current issues on vocational and technical education in Nigeria including current states, problems, and prospects for developing vocational and technical education in Nigeria.

\section{Methods}

The research was based on 'documentary research' in order for the researcher to describe Vocational and Technical Education focal concentrations, current problems and prospects for VTE development in Nigeria. The selection criteria of the document used 'criteria for quality assessment' (Scott, 2006) as follows:

1. Authenticity- is the evidence genuine and of unquestionable origin?

2. Credibility- is the evidence free from error and distortion?

3. Representativeness- is the evidence typical of its kind, and, if not, is the extent of its untypicality known?

4. Meaning- is the evidence clear and comprehensible?

Data were analyzed mainly by content analysis. The documentary data was examined under the headings of (1) source of the document; (2) audience - for example the Board of Trustees or Principal; (3) relevant text to expectations for principals leading learning; (4) analysis - an interpretation of what each document is saying to the intended audience. This involved considering the clarity of the message of each of the documents. "Documentary analysis is a form of qualitative analysis that requires readers to locate, interpret, analyse and draw conclusions about the evidence presented" (Fitzgerald, 2007). According to Wellington (2000) documentary research can be used as a main focus for educational research or as an adjunct.

Information was gathered and analysed from a range of sources that held relevance to the current issues on vocational and technical education in Nigeria. These were:

- Refocusing Nigerian Vocational Education for Relevance and Sustainable Development (Apagu and Andural, 2007)

- Maintenance of Standards in Vocational Education in Nigeria: Implications for Students' Occupational Choice and Skills Development (Akpan et al, 2011)

- Vocational Technical Education in Nigeria: Challenges and the Way Forward (Okolocha, 2012)

- Vocational and Technical Education in Nigeria: Issues, Problems and Prospects' Dimensions (Ojimba, 2012)

\section{Findings}

\subsection{Refocusing Nigerian Vocational Education for Relevance and Sustainable Development (Apagu} and Andural, 2007)

Apagu and Andural discussed about VTE in Nigeria awakening of Nigerians and the Federal Republic of Nigeria from the long negligence of vocational education. The authors reviewed some crucial documents indicating that all scholars accept that VTE is very important for country development. The authors concluded strategies for refocusing vocational education in Nigeria in the $21^{\text {st }}$ century, there were:

- Ensuring equality of access to vocational education by all Nigerians

- Coping with possible enrolment explosion in vocational education programmes in Nigeria

- Relevant curricula in vocational education

- Reviving handicrafts subject at the primary school level

- Planned talent search and development

- Adaptation rather than wholesale adoption of the teaching/learning of imported 
technological knowledge/skills

- Suggested vocational perspective of university education The authors concluded that:

It is a thing of joy that Nigerians are now questioning the quantity and quality of vocational, technical and technological education in the country's educational system and among Nigerians. It is therefore, high time the country refocuses her vocational education to serve the nation better. The refocusing could be through further recognition of vocational/technical and technological education, relevant programme curricula, improved funding, further reorientation of youths towards these vital aspects of education in the form of vocational guidance and counseling, planned talent search and development, provision of more teaching/learning facilities for improved enrolment and so on. The time is now; tomorrow may be late.

\subsection{Maintenance of Standards in Vocational Education in Nigeria: Implications for Students' Occupational Choice and Skills Development (Akpan et al, 2011)}

Akpan et al wrote this academic article focusing on standard in vocational education in Nigeria in terms of supervision, curriculum, methods of instructional delivery, equipment, and quality of teaching staff. The authors made some recommendations include: making of the school curriculum to be vocational education-based; drawing up policies that make vocational education the foundation for all forms of education; and employing qualified teachers in all the vocational areas of the school curriculum.

The authors concluded that:

Thus, setting and maintaining standards remain elusive. Since the attainment of rapid technological and socioeconomic development of any developed economy is based primarily on this type of education, Nigeria has to strive to tow the line of the developed nations of the world for her to develop.

\subsection{Vocational Technical Education in Nigeria: Challenges and the Way Forward (Okolocha, 2012)}

Okolocha critically reviewed the micro and macro vocational technical education policies in Nigeria, their current challenges and the way forward. The author stated key challenges to vocational and technical education in Nigeria and also strategies for revamping vocational and technical education include:

- Institute flexible, workable and adaptable programme

- Ensuring high quality and appropriately skilled vocational professionals

- Promotion and proper Coordination of education, Industry and Work Environment

- Encouraging Continuing Vocational Technical Education

- Investing in Quality Vocational Technical Education Programme

- Training and learning should take Place in Authentic and Real Work Environment

- Sharing ratio of Education Trust Fund (ETF) among the Three Tiers of Higher Institutions in Nigeria

- Adoption of Uniform Standard of training and Certification

- Setting up a National and Local Structure of VTE Councils

- Keeping Appropriate/Up-to-date and Indicators for Vocational Technical Education

- Assessment Criteria

The author emphasized thatt:

The success of vocational technical education programme in Nigeria hinges on proper planning, efficient implementation, adequate funding and motivation. The three tiers the 
government needs to re-access and reinforce the implementation of the VTE policies. The focus now should be on the development of a viable natural system of vocational technical education programme that will have easy access and exit learning pathways, which must be validated by accredited learning that will lead to work or continued progress along another learning pathway. This will help to ginger youths and adult to see VTE as challenging and worthwhile not just as a ticket to second-class status and citizens.

\subsection{Vocational and Technical Education in Nigeria: Issues, Problems and Prospects' Dimensions (Ojimba, 2012)}

In this academic article, Ojimba critically examined the issues, problems and prospects of vocational and technical education in Nigeria and suggest ways to improve the teaching and learning of vocational and technical education with enhanced enthusiasm and vibrancy. The author raised issues and problems mitigating the training of technical education or vocational education; there were:

1) Funding

2) Facilities

3) Brain Drain

4) Staff training and retention

5) Staff situation

6) The curriculum of technical education

7) The apathy of political office holders/law makers:

The author suggested the government for a comprehensive reform towards vocational and technical education and a deliberate attempt to uplift the programme is the only panacea to a technological enderado in Nigeria.

\section{Conclusion and Recommendations}

There are many issues regarding VTE in Nigeria. The results showed that there were insufficient concern about VTE in Nigeria especially for those who are unemployed brought about very high unemployment rate nowadays. There are several current issues that have to be governed as they are very crucial for development of the nation. The Federal Governments of Nigeria should give more concern about VTE in all issues mentioned and come up with strategic plans, policies and practices for vocational development of people. Effective poliicies and practices of VTE would bring about better economic development of the nations. Nigeria should begin now to take very seriously investment in vocational and technical education and become not only the most populous country in Africa, but also the most competitive country in international labour market.

\section{References}

Akpan, E. O, Nsa, O. E. \& Akpan, N. A. (2011). Maintenance of Standards in Vocational Education in Nigeria: Implications for Students' Occupational Choice and Skills Development. A Journal of Contemporary Research: 8(4), 45-54.

Apagu, V. V., \& Andural, S. I. (2007). Refocusing Nigerian Vocational Education for Relevance and Sustainable Development. Multidisciplinary J ournal of Research Development: 9(1),1-8.

Federal Republic of Nigeria. (2004). National Policy on Education $\left(4^{\text {th }} \mathrm{ed}\right)$. Lagos, Nigeria: Nigerian Educational Research and Development Council Press.

Fitzgerald, T. (2007). Documents and documentary analysis: Reading between the lines. In A. R. J. Briggs \& M. Coleman (Eds.). Research methods in educational leadership and management (2nd ed.), (pp. 278 - 294). London: Sage Publications.

National Bureau of Statistics. (2012). Nigeria Unemployment Rate. Abuja: National Bureau of Statistics. Retrieved from http://nigerianstat.gov.ng/ 
Ojimba, D.P. (2012). Vocational and Technical Education in Nigeria: Issues, Problems and Prospects' Dimensions. J ournal of Educational and Social Research: 2(9), 23-30.

Okolocha, C.C. (2012). Vocational Technical Education in Nigeria: Challenges and the Way Forward. Business Management Dynamics: 2(6), 1-8.

Scott, J. (2006). Documentary Research. London: Sage Publications Ltd.

Wellington, J. (2000). Educational Research: Contemporary Issues and Practical Approaches. London: Continuum. 
